\title{
H.G. Stoker as student - die wysgerige denkklimaat en akademiese wisselwerking met Scheler en Buytendijk
}

Amold A. Beijk

Buytendijkargief \&

Faculteit der Wijsbegeerte

Katholieke Universiteit

NIJMEGEN

Nederland
N.T. (Theo) van der Merwe

Dept. Filosofie

Potchefstroomse Universiteit vir $\mathrm{CHO}$

POTCHEFSTROOM

\begin{abstract}
This article represents an indispensable part of the total corpus of this issue. It contains a transcription of the letters of H. G. Stoker to F.J.J. Buytendijk, annotated by Arnold Beijk and further illuminated and commented on by Theo van der Menve. This kind of archival material is of immense value in developing a comprehensive vision and overview of H.G. Stoker's work not only for the more casual reader, but more particularly for the serious scholar who can find solid acadenic support in these documents for assumpions made about Stoker's uork. Stoker's creative and illuminating personal style of thinking and writing is well demonstraled here.

The letters reveal very strikingly the course of the academic interaction between Stoker and Buytendijk abowt his study on conscience which he was conducting under the guidance of Max. Scheler. The material also provides fascinating incidental material about Stoker's vision of the country and its universities, more particularly the University of Potchefstroom, at the time. His perspective on his own academic ideals comes out well and lies in with considerations dran'n from the European milien.
\end{abstract}

\section{Inleidend - redaksionele nota}

Hierdie artikel bevat die transkripsie van 'n aantal briewe van H.G. Stoker aan F.J.J. Buytendijk, met toeligtende kommentaar van Amold A. Beijk.

Drs. A.A. Beijk is ' $n$ navorser aan die Buytendijkargief te Nijmegen en is sedert 1991 aan die Fakulteit Wysbegeerte van die Katholieke Universiteit te Nijmegen verbonde. Hy het die Christelike filosofie 'n besondere diens bewys met sy transkripsie van 'n sestal briewe van Stoker uit sy studentejare in Europa. Beijk het in 1982 te Nijmegen in die psigologie met 'n skripsie oor "Ideologie en 
massakommunikasie" afgestudeer. Sedert 1987 het hy 'n filosofiese dieptestudie van $F$. Nietzsche onderneem en is vanaf 1990 besig met 'n doktorsgraadprogram oor die fenomenologie in die algemeen en dié van Buytendijk in die besonder. Benewens 'n aantal wetenskaplike publikasies op sy naam was daar ook reeds verskeie kunsuitstallings van sy werke en is hy sedert 1977 intens by kultuurmanifestasies en radioprogramme betrokke.

N.T. van der Merwe was behulpsaam met die finale redigering, waaronder die keuse van moontlike alternatiewe lesings, interpretasies en spelling van woorde, asook die indeling van die hoofdele van die getranskribeerde briewe.

Sekere toeligtende agtergrondgegewens wat aanvanklik deur Arnold Beijk in voetnote gegee is, word in 'n oorsigtelike gedeelte van hierdie artikel aangebied (2 - Agtergrondgegewens). Meer inligting oor die aard en voorbereidingsproses van hierdie briewe word in die daaropvolgende gedeelte (3) deur N.T. van der Merwe gebied. Die transkripsie self en Beijk se verduidelikende notas volg dan in die laaste gedeelte van die artikel (4). $\mathrm{Na}$ hierdie gedeelte volg 'n kort uittreksel uit 'n brief in prof. Stoker se handskrif (5).

Ter wille van groter lesersvriendelikheid is die briewe self, asook gedeeltes daarvan, redaksioneel van opskrifte voorsien (Redaksie - Koers).

\section{Agtergrondgegewens}

Buytendijk was die persoon wat Stoker aanvanklik na Scheler vir doktorale studie aanbeveel het en binne dié kader moet hierdie briewe van die jong student Stoker gelees word. Stoker het gedurende sy nagraadse studiejare in Europa noue kontak gehad met die bekwame en oorspronklike fisioloog en natuurfilosoof Buytendijk, wat op daardie stadium aan die Vrije Universiteit van Amsterdam verbonde was.

Buytendijk (1887-1974) is in 1913/14 benoem aan die Amsterdamse VU waar hy assistent word in die biologiese laboratorium van die Valeriuskliniek wat onder leiding van die psigiater L. Bouman gestaan het. Sy suksesvolle studie in die psigiatrie en neurologie loop in 1919 uit op 'n hoogleraarskap in fisiologic en algemene biologie. Hy kan beskou word as die grondlegger van die fenomenologiese antropologie in Nederland met verskeie baanbrekende studies op sy naam.

Max Scheler (1874-1928), die Duitse filosoof onder wie se leiding Stoker sy proefskrif oor die gewete voltooi het, word soms ook wel die katolieke Nietzsche genoem. Benewens benoeminge aan ander instellinge was Scheler direkteur van die 'Institut für Sozialwissenschaften' te Keulen en aansluitend daarby hoogleraar in Filosofie en Sosiologie aan die Universiteit van Keulen. Sy publikasies getuig van briljante en oorspronklike wysgerige insigte verwerf met sy eie nuanse van fenomenologie. 
Stoker se briewe uit die twintigerjare - die periode waartydens hy aan sy magistrale proefskrif oor die gewete gewerk het - is belangrik daar dit enersyds 'n kyk op die vroeë wetenskaplike ontwikkeling van 'n groot denker verskaf en andersyds ook ' $n$ idee van die heersende Europese en Suid-Afrikaanse denkklimaat van daardie tyd bied.

\section{Die transkripsie en verwerking van die briewe én hul boodskap}

Die briewe van Stoker wat deur Beijk getranskribeer is, word in die Buytendijkargief te Nijmegen bewaar. Hierdie soort argiefmateriaal is onontbeerlik vir 'n geheelsoorsig oor die ontwikkelingsgang en werk van H.G. Stoker. In lyn hiermee bied dit uit wetenskaplike oogpunt vir die Stokernavorser 'n ondersteuningsfunksie om 'n omvattende beeld van Stoker te vorm. Ook gee die briewe blyke van Stoker se skerpsinnige omgang met die taal en sy kreatiewe en helder denkkrag.

Beijk het die transkripsietaak met verbasende sukses uitgevoer as daar rekening gehou word met onder andere die volgende onstandighede:

* Die moeite wat Beijk as buttelander gedoen het om hom in die denk- en taalmilieu van Stoker gedurende die twintigerjare in te werk.

* Op grond van die vloeibaarheid van geskrewe Afrikaans gedurende hierdie tyd dit soms uiters moeilik is om vanuit die handskrif finaal te beslis watter letters bedoel was. Die probleme op hierdie vlak is meestal eerder filologies as filosofies van aard.

* Die wyse waarop Stoker hom soms in sy skryfstyl by die posisie en milieu van die geadresseerde aanpas, waardeur diskrepansies met ander gedeeltes in die briewe veroorsaak word.

$\mathrm{Na}$ ontvangs ook van fotokopieë van die briewe en die bestudering daarvan, het daar by my (N.T.v.d.M.) 'n vernoede ontstaan dat daar hier en daar 'n alternatiewe interpretasie van die teks ter sprake kan wees. In samewerking met Beijk kon sodoende ' $n$ aantal verbeteringe aan die teks aangebring word. Hierdie werkwyse het my ook in die geleentheid gestel om die transkripsiewerk van Beijk tekstueel te kon evalueer - 'n proses wat my tewens die kompleksiteit daarvan beter laat besef het.

Die oorspronklike manuskrip van Beijk is deur my filologies rekenaannatig verwerk en gefinaliseer. Ook is 'n alternatiewe, ietwat meer omvattende seleksie uit die briewe gemaak wat ' $n$ meer koherente en sinvolle eenheid van die briewe as geheel bewerkstellig. Die bykomende gedeeltes is getranskribeer en verwerk en bied tans saam met die res die teks wat hieronder gepubliseer word. Die strekking en boodskap van die briewe word myns insiens goed deur die titel by 
gedeelte 4 hieronder weergegee en bring die essensie van die leefwêreld en denkklimaat van die briewe aan die lig.

Die briewe gee blyke van die akademiese gesprek tussen Stoker en Buytendijk met kostelike gegewens oor die verloop van die studie oor die gewete onder leiding van Scheler. Dit bied 'n merkwaardig volwasse insig in en waardering van Scheler en Buytendijk. So sou 'n mens seker met goeie grond die intellektuele milieu van H.G. Stoker as skrywer oor die gewete die raster van sy briewe kon noem. Hierdie inhoud borrel egter telkens oor. Dit bevat tewens persoonlike kanttekeninge en ook enkele grepe uit Stoker se belewing van die Suid-Afrikaanse en universitêre situasie van daardie tyd - waaronder 'n unieke prentjie van sy alma mater te Potchefstroom en sy interessante evaluasie van verskeie dosente aldaar. Hierdie briewe laat die lig val op die ideale van 'n jong akademikus en die wysgerige temas wat gedurende sy studiejare in sy belangstellingsveld gestaan het. Ook toon dit sy aandag aan en belang by diverse afdelings van die Filosofie, Psigologie en Opvoedkunde. Die briewe bied verwysings na sy studie, asook na sy belangstelling in bepaalde toonaangewende Europese geleerdes en sy planne vir verdere studie by sommige van hulle. En ten slotte fokus die briewe op sy toekomsideale vir sy latere lewe en beroep, asook sy taak in Suid-Afrika.

\section{Enkele tegniese prosedures by die redigeer van die briewe}

In die redigering van die manuskrip is ' $n$ konserwatiewe benadering gevolg om so na moontlik aan die manuskriplesing te kan kom deur byvoorbeeld [] te gebruik vir die aandui van ontbrekende letters en \{\} om 'n foutiewe of oorbodige leesteken aan te dui. Diskrepansies waarvoor 'n rede (mag) bestaan, is nie kunsmatig geëlimineer nie, en meer as eens is uit die konteks oor moontlike alternatiewe lesings van die handskrif beslis. In die oorspronklike briewe is sommige woorde onderstreep. Hierdie onderstrepings is in die transkripsie behou. Die skryf- en spelwyse wat Stoker gebruik het, is ook onveranderd behou (kyk byvoorbeeld twede i.p.v. tweede en Zuid Afrika i.p.v. Zuid-Afrika).

In die volgende gedeelte van die artikel volg nou die teks van die briewe en die verhelderende kommentaar van Beijk. 


\title{
4. Het geweten: cen perspectief op aspecten van het intellectueel milieu van een filosofisch dissertatie - uit de brieven van Hendrik G. Stoker aan F.J.J. Buytendijk
}

\author{
Ingeleid en geannoteerd door Arnold A. Beijk
}

\subsection{Inleiding}

De Afrikaner Hendrik G. Stoker (geb. 1899) verbleef van 1922 tot 1924 twee en een half jaar voor studie in Europa. Via een aantal kontakten kwam hij uiteindelijk bij Buytendijk terecht die voor hem een plaats bij Max Scheler in Keulen regelde (zie Beijk, 1992a). In Keulen schreef Stoker onder leiding van Scheler een proefsclırift over het geweten. Ondertussen hield hij Buytendijk in een zestal brieven ${ }^{1}$ op de hoogte van zijn vorderingen en belevenissen. De brieven bieden onder meer een interessante kijk op de persoon en het werk van Scheler op dat moment. Ook geven ze een beeld van een onderdeel van de geschiedenis van intellektueel en universitair Zuid-Afrika.

Maar bovenal vormen de brieven, in een bezielde en schone stijl, een verslag van een jong wetenschapper die vanuit het verre Zuid-Afrika naar Europa kwam on te studeren; in kontakt met enkele van de meest vooraanstaande geleerden uit die tijd, Buytendijk en Scheler, uiteindelijk magna cum laude promoveerde - en weer terugkeerde naar zijn vaderland.

\subsection{Excerpten uit een zestal brieven aan Buytendijk}

\subsubsection{Brief 1: 26 November 1923}

\subsubsection{Toekomstplannen}

' $k$ Heb besloten daarvan af te zien nog ' $n$ Dr. graad te halen na deze onder Prof. Scheler, omdat ik mijne krachten sparen wil ... Daannee zie ik niet af van 't

1 De ocrstc dric bricven (26.11.1923: 19.3.1924: 6.5.1924) vanuit Keulen waar hij bij de assistente cn aanstaande echtgenote van Scheler, Maria Sclicu, verblecf: de vierde (8.7.1924) vanuit Amersfoort, enkele dagen voor zijn thuisrcis: de vijfde (21.7.1924) vanaf de R.M.S. 'Balmoral Castle' vlak voor het binnen lopen in Madcira: de zesde na zijn terugker in ZuidAfrika vanuit Johannesburg (1.9.1924). De bricven bevinden zich in de Collectie Buylendijk van het Katholick Documentatic Centrum te Nijmegen (Inventarisnummer 343).

Op dezelfde plaats bevinden zich nog cen vijftal bricven van Stoker aan Buytendijk (London, 8.10.1930; Potchefstroon, 15.3.1939; Potchefstroom. 4.5.1962; Ansterdam. 14.12.1962 cn Zuid-Afrika, 1970) waaruit blijkt dat Stoker on Bustendijk hect hun leven met elkaar in kontakt zijn gebleven en clkaar ook. zij het met grote tussenpozen. incidentecl weer ontmoct hebben. Van de bricven van Buytendijk aan Stoker is in de Coll. Buylendijk slechts cen bewaard gebleven (Utrecht, 16.1.1962). 
werk, waartoe U mij bezield hebt, $n 1$. Deemoed als ' $n$ grondprinciep van Kristelike opvoeding en pedagogiek ${ }^{2}$ uit te werken, integendeel hoop ik juist in deze richting verder te arbeiden, totdat ik rijp genoeg ben hierover 'n werk te publiseren; ik ben echter vol ${ }^{3}$ overtuigd, dat 't niet als dissertatie, maar eigenlik als 'n levenswerk opgenomen worden moet. Nog steeds ben ik bezield en doordrongen van die diepe gedachten in Uw werken over opvoedkunde ${ }^{4}$ en wezensverschil tusschen mens en dier ${ }^{5}$ - en van de werken van Max Scheler.

Wat ik in de toekomst nog doen ga, betreffende mijn verdere studie, hangt eensdeels daarvan af of Prof. Van Rooy zich tot verdere studie finaal besluit; - op mijn programma blijft bestaan: 1 semester naar Stern, 1 semester (ten minste) naar Amerika, misschien ook nog 1 semester naar Kerschensteiner $-\{-\}$ ongelukkig valt dus naar alle waarschijnlikheid om onder uw leiding in Amsterdam 'n jaar te studeren weg. Dat spijt me biezonder, omdat ik door Uw oorspronkelike en diepe blik en inzicht in de problemen veel hulp en leiding verwacht, vooral in onze Kalvinistiese ${ }^{6}$ en Phänomenologiese gemeenschappelike belangen; en omdat 't me altijd ' $n$ innige vreugde en bezieling was met $U$ over zulke problemen te spreken. ... Mijn besluit is me zelf des te onaangenamer, wat mijn studie onder $U$ betreft, omdat ik U zoveel verplicht en door Uw hulp en raad zo persoonlik met Prof. Scheler bekend en bevriend geworden ben, waarvoor ik Uw steeds dankbaar blijven zal.

De Berlijnse studie was me eensdeels zeer veel waard. Mannen zoals Sombart, Spranger, Köhler, Wertheimer ${ }^{7}$ te horen verruimt zeker de blik; anderzijds hebben ze me allen niet gegeven wat een semester Scheler zijn studenten geeft hij is door zijn diepte en genialiteit en tegelijk door zijn veelzijdige en veelomvat-

2 "Gehecl anders bij het decmocdige denken. Hierbij is niet het begrijpen, maar het zien. het inzien de bepalende acte der ziel. De dingen, de werkelijkheid zien, niet in ons licht, onze vormen, maar in hun cigen licht, dat ze dus van God ontvingen, in het licht van Gods openbaring, van zijn woord, niet te omvatten, maar slechts teder aan te voclen, met om in zich op te nemen, maar om zich crin te verliczen" (zic Buytendijk, 1922a: uitgave 1962:8) Bùtendijk sloot hicrin aan bij ecn ecrder artikel uit 1921 over 'De decmoed' in De Reformatie dat geïnspireerd was door een artikel van Scheler uit 1913: "Zur Rchabilitierung der Tugend".

3 Misschien: ik ben echter ook overtuigd.

4 Zic Buytendijk (1922a) en vgl. de context van noot 2

$5 \quad$ Zic Bustendijk (1922b)

6 Buytendijk zal zich in 1937 tot het katholicisme bekcren; zic Lap \& Struyker Boudicr (1987: 26-31).

7 W. Sombart (1863-1941), Duits socioloog, historikus en ckonoom: E. Spranger (18821963), Duits filosoof, psycholoog en pedagoog: W. Köhler (1887-1967), Duits-Amcrikaans psycholoog, met M. Wertheimer en K. Koffka grondlegger van de Gestaltpsychologie; M. Wertheimer (1880-1943), Oostenrijks psycholoog 
tende algemene kennis een van de allerbeste van Duitsland. 't Is en blijft bezielend zijn in die diepte worstelende voorlezingen te horen.

\subsubsection{Over Scheler: ontwikkeling van zijn pan-en-theïsme}

Scheler heeft veel doorgemaakt en veel geleden door de geschiedenis met zijn vrouw, van wie hij nu gescheiden is. Hij zag in Julie en Augustus biezonder slecht uit, en was in verschillende Sanatoria om zijn krachten te vemieuwen. Nu is hij er doorheen, veel gezonder en werkt met ijver, - alleen de noodlottige finantiele toestanden heeft hem bij zijn metaphys[iese] spekulatieèn ook voor finantiele spekulaties belangstelling gegeven, - en ook hij zoekt, zooals elke Duitser, zijn inkomen in vaste waarde in goeie papieren te steken; ' $t$ vallen en stijgen dezer papieren neemt zijn emotionele aanleg soms zo in beslag, dat de metaph[ysiese] spekulatie eronder lijden moet, en dat is jamıner. Ook met de politieke ontwikkeling leeft hij mee, alsof 't zijn eigen ontwikkeling is, en wordt daardoor zeer pessimistisch. Kon Scheler hem van al deze emotionele doorlevingen losrukken, zou 't de wetenschap zeker ten goede komen.

Toch vindt hij tijd genoeg om zich aan de wetenschap zo te wijden, dat hij vooruitgang voelt en tevreden is. Over 't probleem: dood en leven (waarover hij nu 'n schitterende publieke reeks voorlezingen houdt) en "altern" heeft hij veel dieperes gevonden. Ook zijn metaphysica (waarover hij nu de private studenten voorlezing[en] geeft) verdiept hij elke keer en komt tot nieuwe ontwikkeling. Over Ethiek en Ken-theorie houdt hij twee "seminaren" voor zijn studenten.

Scheler verlaat de reine theïsme en wordt al meer en meer pan-en-theist. Zijn metaphysica geeft zijn "systeem", waarin alle speciaal-onderzoekingen tot een geheel zich zamen-gehouden voelen'. Zonde, pijn, smart, 't boze kent hij niet meer door 'n katastrofe in 'n oorspronkelik algoede volkome schepping, - maar verlegt in God ' $n$ irrationeel moment, wat finaal dit alles verklaren moet. In den

8 Vgl:: "Denn jede der grossen Abteilungen des menschlichen Wissens und sciner Gegenstände hat scine eigentümliche 'meta-'Probleme, scine 'Mctaszicnz', dic von den positiven Einzelwissenschaften bewusst vernachlässigt werden und zweeks fruchtbarer gemeinsamer Arbeit auch vernachlässigt. zurückgestellt werden sollen: nicht also nur dic Physik, wenn auch in weiten Sinne des Aristoteles verstanden. Diese Metaszienzen sind dic Verbindungsbrücken zwischen den positiven Einzelwissensehaften und den obersten und höchsten Teil der Mctaphysik: der Lehre vom Weltgrund, indem sic zu zeigen haben, wic ihre Gegenstände zu ihm stchen. Weltgrund heisst hier: Abschluss. Koinzidenzpunkt der diversen Richtungen der Realität der Metaszienzen.

Metaphysik ist daher in diesem Sinne. d.h. im Gegensatz zu den Teil- und Einzelwissenschaften. auch Totalitäts- und Universalkenntnis - 'Wcltweisheit'. Sic re-integriert dic Zerteilung und Differenzicrung. welche dic positiven Fachwissenschaften in Jahrhundert währender Arbeitstcilung vorgenomen haben, kraft ciner cigentümlichen, nur ihr und keiner anderen Wissensart zukommenden Mcthodik" (Scheler. Gesammelte Werke. 11:12). 
beginne was God alwijs en algoed, niet almagtig. 'n Drang tot realisatie, tot schepping, was machtiger [in] hem. In 'n tijdloos-worden ontwikkelt God zich tot beheersing van die drang', zijn eind-toestand is 'n volkome God, die ook almagtig is. Daarin moet ' $n$ ieder van ons meestrijden, zichzelf beheerschen ten goede om solidaries met God en door God deze eind-toestand te bereiken ${ }^{10}$. ' $t$ Boze, kwade, nu, is: waar deze drang in de menschen (want God heeft geen slecht element in zich) goede ideën ziet en erkent en toch nog de sleclite, minderwaardige verkiest en doet. Alles is ten slotte in God, de schepping is uit God door deze drang "herausgesprudelt". - Scheler blijft dualist: drang en Einsicht in God; geest en leven ook; natuurphilosophies verlaat hij 't dualisme en wordt panvitalisties. - Ik geloof niet dat Scheler in deze ontwikkeling bevredigd voelen zal; 'n pan-en-theïsme, geboren uit "'n diepe religieuze behoefte" in hem (zoals hij me zeide), kan niet absolute rust geven. Zeg eens, heb ik Prof. Scheler gevraagd, dat God niet tot deze zelfoverheersching komt, dat de drang sterker blijft als God, dan schudt 't heelal op zijn fondamenten. Wij moeten geloven dat God deze drang overwinnen zal, en hero[ï]es ons eigen leven op dat doel heen richten, was zijn antwoord" ${ }^{11}$.

\subsubsection{Brief 2: 19 Maart 1924}

\subsubsection{1 "De liefdesprinciepe"}

$\mathrm{Na}$ ' $\mathrm{n}$ paar maanden intensieve arbeid aan mijn dissertatie, voel ik dat ik ' $\mathrm{n}$ heel stuk verder gekomen ben en 't eind altyd meer nader; de diss[ertatie] is veel groter geworden als oorspronkelik gedacht, en indien ik 't zo uitwerken wil, als ik

$9 \quad V g l .:$ "Letztlich geht es Ihm darum, 'dic Welt als Geschichte' zu fassen. Und seine Hoffnung ist, dass sich doch allmählich diese Welt, 'zunächtst cin wüster Traum der Gottheit als Drang' hinentwickelt zu cinem Kosmos. Er fühlt sich in der 'Mitte der Zcit' angekommen, in der eine Vergeistigung begonnen habe. Vergeistigung heisst: das Sosein, der ohnmächtiger Geist gewinnt Realität" (zic Mader, 1980:130).

$10 \mathrm{Vgl}$.: "Das, was Mctaphysik möglich macht. ist letzten Endes ... dic Doppeltcilhabe des Menschen an dem zeugenden begrenzten Scin und Wirken des Weltgrundes selbst: Die substanticlle Identität (partielle) des menschlichen Geistes mit dem göttlichen Geist und des menschlichen Trieblebens mit dem göttlichen Drang" (Scheler, Gesammelte Werke. 11:90).

Vgl. ook: "Der Mensch ist also nicht Nachbildner ciner an sich bestehenden oder schon vor der Schöpfung in Gott fertig vorhandenen 'Ideenwelt' oder 'Vorschung', sondern er ist Mitbildner, Mitstifter und Mitvollzicher einer im Weltprozess und mit ihm selbst werdenden ideellen Werdefolge" (Scheler, Gesammelte Werke, 9:83).

11 Vgl.: "Der Wert und der Sinn der Geschichte liegt nicht im Anfangszustand (Romantik) oder Endzustand, sondern in der Sinnvollen Kooperation der Generationen, der Epochen. der Völker, Rassen, Kulturkreisc - und zwar alles Zeiten - zur Mitrealisierung des Guten und des höhcren Wertcs" (Scheler, Gesammelıe Werke, 11:70). 
't nu in mijn hoofd heb, dan wordt hy nog veel langer; maar ik kort nu zoveel mogelik to ' $n$ eenheid af, want ik verlang emaar mijn Dr. eksamen achter de rug te hebben; later zal ik 't zo kunnen verdiepen en uitwerken als ik wil. Als metafiesiese grondeenheid van 't Phenomen heb ik de Liefdes-princiepe van $\mathrm{U}^{12}$ en Schelerl3, want 't spreken van 't geweten is ten slotte toch 't her-ontwaken van de liefde, de verband van God en inensch, in 't individu; zolang die liefde ontbreekt, zwijgt 't geweten. U weet niet, van hoeveel vrucht Uw "Wezensverschil tusschen Mensch en Dier" voor me geweesd is. 't Spyt me dat nu voor mijn eksamen de tijd ontbreken zal nog dieper 't wezensverband van 't geweten tot deze liefde uit te werken, als tot zover gedaan. Hoe groot en hoe zwaar dit onderwerp ook was, $i k$ voel toch volle bevrediging dat ik ' $t$ aangedurfd heb en met Gods zegen eraan gebleven ben; veel rijker ben ik er zeker door geworden.

Gedeelten heb ik Prof. Scheler voorgelezen. Hij was heel tevreden daarmee en zal, als 't geheel die standaard heeft, 't uitgeven in zijn reeks Philosophiese Werken, waarin Landsberg ook zijn dissertatie heeft mogen plaatsen.

Scheler genict nu 'n welverdiende rust. Hij was biezonder afgewerkt dit semester. De vakantie-plannen zijn: Itali[ë]. Hij heeft heel veel privaat gewerkt vooral aan de relig[ieus] philosophische problemen en zegt dat hij veel gevorderd is; ook aan de problematiek van: 'Entwicklungsstufen der Seele' waaronder biezonder de "Psychologie des Alterns", heeft hij veel kunnen verdiepen. Met de studenten behandelde hij hoofdzakelik zijn metaphysica en [in] de Seminaren zijn Ethiek en zijn Kentheorie, en in de publicé: probleem van dood en leven. Alles biezonder diep, rijk en breed. Zulk 'n semester is goud waard.

\subsubsection{Alternatieve studieprogrammas}

... Na deze rustdagen ga ik weer met jjver aan 't werk en hoop D.V. in Juni te mogen promoveren.

De vraag is nu: wat daama? En hierin zou ik heel graag Uw raad en leiding hebben wil.

12 "De ceuwen door werd het herhaald, dat wij de dingen slechts kennen in zoverre wij ze beminnen. Dichters en denkers hebben vanuit hun diepste ervaring bevestigd, dat het hart het werkzame ken-orgaan is voor de waarden en dus voor het cigenlijke zins-verband van wat wordt ontmoct en in zijn feitelijke uitwendige verschijningsvorm waargenomen, in zijn algemene wetmatigheden beschreven kan worden" (Bustendijk. 1958:9).

13 'Ohne ein Tendenz in den Scienden. das 'weiss', aus sich hervor- und herauszugehen zur Teilhabe an einem anderen Seicnden, gibt es überhaupt kein mögliches 'Wissen'. Ich sche keinen anderen Namen für diese Tendenz als Liebe, Hingebung: gleichsam Sprengung der Grenzen des cigenen Scins und Sosein durch Licbe" (Scheler. Gesammelle Werke, 8:68; 9:1(1). 


\subsection{Eerste richting}

Mijn plan was eerst:

Julie - November '24: Vakantie reis naar Afrika om mijn meisje en mijn ouders op te zoeken. November '24 - Augustus '25 aan enkele univ[ersiteiten] in Europa te studeren en me vooral toe te leggen op: Kinderpsychologie, en Exper[imentele] Psychologie, en Paedagogiek, om, wat 't laatste betreft, in 't biezonder te werken aan de vraag: Karakter en Opvoeding (ook dus Persoonlikheid, Liefde, Deemoed en Opvoeding). Augustus '25 - ? (6 of 8 maande) naar Amerika on de Engels-Amerikaanse Kultuur, en beschouwing der problemen te bestuderen, maar vooral ook om de taal zo goed mogelik als spreek- en schryf-taal in me op te nemen terwille van mijn as. loopbaan in Afrika. Na de Amerikaanse studie hoopte ik in Afrika 'n betrekking te vinden ...

Wat de 2-semesters Europese studie (na Dr. eksamen) betreft, was de grote vraag: waar? En vooral hierop zou ik graag Uw raad willen hebben. Ik heb nu de meer filosofiese studie bijna agter den rug (wat mijn buitelandse studie betreft), en zou graag nu ook met de experimentele Psychologie en Paedagogiek in aanraking willen komen, zoveel mogelik, on in de overige tijd 't Karakterprobleem aan te pakken. ' $k$ Heb gedacht aan Amsterdam, Hamburg (Stern), Marburg (Jaensch), Wien (Bühler), Giessen (Koffka), München, Zürich, Leipzig. In deze studie wil ik in hoofdzaak net de genoemde problemen aanpakken, maar ben niet van plan ' $n$ twede Dr. graad erbij te halen, dat belemmerd de vrije studie te veel, is bovendien niet zo nodig, en eist mis[s]chien te veel intensieve inspanning van mijn krachten. Wat zoudt $U$ me aanraden waar en hoe ik nog 'n jaar studie in Europa geven zou?

Dit is de eene richting waarin mijn studieplamnen uitlopen kumnen.

\subsection{Tweede richting}

Maar nu duikt er plotseling ' $n$ twede richting op, welke ik niet weet of 't het beste is dat te verkiezen of niet. Ook hierin zou ik graag Uw raad hebben willen

Ik heb nl. van Professor van Rooy ' $n$ brief ontvangen met de vraag of ik hem niet vanaf 1 Maart 1925 tot 30 September '25 aan de Potchefstroomse Universiteit aflossen wil. Hij is Prof. in de Philosophie (de enigste op 't ogenblik en heeft onder zich Psychol[ogie], Ethiek, Ken-theor[ie], Metaphys[ica], Geschiedenis van [de] Philos[ophie] voor de drie universiteitsjaren.) Hij wil dan privaat verder studeren en vooral aan de Johannesburgse Universiteit enkele geleerden loren.

Neem ik zijn voorstel aan, dan is de vraag of ik voor 1 Maart '25 in Europa blijven zal, en waar ik die tijd studeren zal, - en of ik na 30 September '25 naar 
Amerika alleen ga, en of ik Amerika totaal opgeven zal en nog een jaar naar Europa komen zal, en waar, - en of ik mischien in 't geheel nie weer terug kom en ' $n$ betrekking daar zoeken zal. Deze voorstel aan te nemen betekent wel de eenheid van mijn studie hier na mijn Dr. graad totaal te breken. Die 7 maanden in Afrika kan ik net extensief werken om studenten voor de eksamens voor te bereiden, van intensieve studie is geen sprake, nog minder om mijn filosofies-pedagogiese problemen aan te pakken en te verdiepen. Ik krijg wel ervaring in de praktijk van onderricht, dat heb ik ook nodig ... - maar ik breek mijn studie voor ik klaar ben, en dat is 'n nadeel; en die paar maande voor de Afrik[aanse] onderricht-maande en die paar maande daarna, lijk wel [iets?] op lapwerk ... doe ik niet verstandiger eerst mijzelf zoveel mogelik te bekwamen om daanna al mijn krachten aan Potchefstroom te geven?

U voelt zeker mijn moeilikheden. 't Voorstel van Prof. van Rooy trekt me biezonder ... maar mijn oorspronklike plan eerst de idealen van mijn studie te verwezenliken, eerst zoveel mogelijk "af te studeren" trekt me ook biezonder.

$U$ zult me zeer verplichten als $U$ me hier $U w$ raad geven kunt in al deze problemen. En waar ik toch waarschijnlik volgens plan a en plan $\underline{b}$ beide: nog 1 semester na Julie in Europa studeer, en daana de richtingen uit-een-lopen, zou 't me zeer aangenaam zijn als $U$ me voor dat semester raden kunt, waarheen 't voor mijn plannen 't beste is om [?] te gaan studeren.

Om $U$ 'n beter overzicht te geven, heb ik de beide plannen op de ommezijde naast elkaar gegeven. Of is er mischien 'n 3 de uitweg?

Plan a

Jul. - Nov. '24

Vakantie Afrika

Nov. '24 - Aug. '25

Europa - waar?

Exp[erimentele] Psych[ologie]

Kind[er] Psych[ologie]

Paedag[ogiek] (Karakter en

opvoeding)

Aug. '25 - \pm Febr. of April '26

Amerika (?)

\section{Plan b}

Jul. '24 - Febr. '25

Europa, - waar?

Maart '25 - 30 Sept. '25

Afrika - Prof. Van Rooy's

plaatsvervanger

Sept. '25 - Julie '26

Amerika of Europa: waar? 
Daarna: Finaal terug

naar Afrika
Daarna: Finaal terug

naar Afrika

Gaarne zou ik $U$ nog een en ander van mijn diss[ertatie] meegedeeld hebben, maar ongelukkig heb ik nu niet voldoende tijd. Ingeval 't gedrukt wordt, stuur ik beslist een aan $\mathrm{U}$...

\subsubsection{Brief 3: 6 Mei 1924}

\subsubsection{Voorlopig noch niet naar Potchefstroom}

Met betrekking tot mijn vorige brief wil ik $U$ graag meedele, dat ik besloten heb de plaatsvervanging van Prof. $v$ [an] Rooy nu niet over te nemen, daar 't mijn studies te veel uit elkaar scheurt, wat ik vermijden moet, vooral waar ik, als ik eenmaal finaal in Afrika ben, niet weer die grote gelegenheid hebben zal mij zo goed als mogelik voor mijn toekomstige roeping voor te bereiden ... Dus blijf ik vanaf November nog twee semesters in Europa, en mis[s]chien 'n maand of 6 in Amerika of Engeland. Maart - April 1926 hoop ik finaal af te kumnen sluiten met mijn studieën in ' $t$ buitenland en met volle bezieling aan ' $t$ werk te gaan. Ik hoop en vertrou in Potchefstroom aan de Uni[versiteit] aldaar 'n benoeming te zullen krijgen.

$\mathrm{Nu}$ is de vraag: waarheen de volgende twee semesters, waar ik op mijn programma 3 punten heb: 1. Kinderpsychologie (als tegenstelling tot dierpsychologie). 2. eksper[imentele] Pädagogiek en eksper[imentele] Psychologie - als tegengewicht tegen mijn tot dusver meer filosofies gekleurde studie. 3. Karakter (persoonlikheid) en Opvoeding, als 'n grondbeginsel voor de Paedagogiek. 3. sal ik meer privaat afwerken, $1 . \& 2$. wil ik meer universitair volgen. Wat raadt $U$ mij hierin aan?

\subsubsection{2 "Niet 't Hoofd maar't Hart ... zentrum van 't geweten"14}

Mijn dissertasie is gelukkig klaar, en heeft een veel groter omvang als ik verwacht had. 't Heeft ook 'n eigen oorspronkelike kleur en theorie, en ik ben benieuwd te weten wat prof. Scheler zegt, als hij 't helemaal gelezen heeft. Mijn grond these is: niet 't Hoofd maar 't Hart's is 't zentrum van 't geweten, 'n objektieve Emotionalisme heb ik verzocht uit te werken.

14 Zentrum: $z$ hier en elders waarschijnlijk vanuit Duitsc levenscontext; vgl. ook 'Phenomen' bij 4.2.2.1.

Vgl. noot 12. 
'n Twede grond these is: 't geweten, wanneer 't uit konsekwente biologiese en sosiale oogpunt beoordeeld wordt, moet noodwendig als 'n "psychopathologische Erkränkung"l6 aangezien worden; wil men de Ernst en "gezondheid" van 't geweten redden, welke 't geweten in zichzelve betuigt, dan moet het uit 'n überbiologisch en über-sozial oogpunt beschoudt worden. 3. Is 't geweten dus überbiol[ogisch] en übersoz[ial] als 'n diep-innig "normale" verschijnsel te verstaan, dan is 't metaphysies toch weer 'n "Symptom der Erkränkung". 4. 't Geweten als "die reëlle innere Kundwerdung des personal Böses in uns - sei es verwirklicht (böses Gewissen), sei es zur Verwirklichung drängend (warnendes Gew[issen]), sei es prinzipiell möglich aber reëll verneint (gutes Gewissen)"17, is absoluut vertroubaar en "unfehlbar". Want, niet de ken-theoretiese uitspraak over wat goed of kwaad is, maar de waarheid dat wel of niet in ons iets "Böses" zich in ons beweegt heeft is de inhoud van 't geweten. Zeker\{,\} knoopt 't gew[eten] aan de ons in onze kennis gegeven boosheid aan, maar 't kennen des "Bozen" is nog geen geweten, - 't als boos, sonde, - erkende ook te willen, te begeren, of te vermijden is de vraag waarover ' $t$ geweten zich bekommerd. Wat ik als slecht erken en wil, - dat ik dus door 't slechte te verkiezen ook slecht ben, - deze boze neiging in ons, 't boze prinsiep in ons, reageert 't geweten tegen, niet tegen de kennis van ' $t$ boze. En hierin is ' $t$ geweten onfeilbaar, even onfeilbaar als ik in 'n haat ook weet dat ' $t$ haat en geen liefde is, die ik voel.

Als mijn dissertasie ${ }^{18}$ gepubliseerd wordt, zal ik $U$ onmiddellik een sturen. Tot dusver wordt 't nog net in 'n aantal eksemplaren getypt, waarna ik 't aan de Univ[ersiteit] afgeven moet.

\subsubsection{Over Scheler's wijsgerige interesse}

Prof. Scheler is naar Napels naar 't Wereld-philos[ophen] Kongres. Hij is nu met Fräul. Maria Scheu gehuwd 19. Ik hoop dat dit huwelik gelukkiger zijn mag als de vorige twee 20 . Prof. Scheler sprak erover $U$ 't volgend semester weer eens voor enkele dagen hierheen uit te nodigen.

Aan drie problemen geeft Scheler tegelijk zijn aandacht, welke hij ook zo spoedig mogelik publiseren wil: a. De panentheistiese grondprobleem van zijn Philo-

16. Stoker (1925:182 c.v.).

17 Stoker (1925:210).

18. H.G. Stoker, 'Gewissensphänomenc. Einc psychologisch-philosophische Studic', manuskript 1924.

19 Schcler trouwde 16 April 1924 met Maria Scheu (1892-1969).

20 Scheler trouwde in 1899 met Amclic Wollmann (1867-) en in 1912 mct Märit Furtwängler (1891-1971) 
sophie waarin hij veel beinvloed is door Karl Barth's Der Römerbrief ${ }^{21}$ en Jakob Bölumes 22 Panentheisme. b. Zijn Erkenntnis-theorie 23 en Metaphysik ${ }^{24}$. c. Entwicklungsstufen der Natur ${ }^{25}$ - wezensverschil tusschen Plant, Dier en Mensch.

$\mathrm{Na}$ mijn promotie, einde Junie ben ik van plan voor 4 maanden naar Afrika te gaan en hoop $U$ nog in Amsterdam op te zoeken voor mijn vertrek zo tusschen 5 en 12 Julie, als $U$ nog daar bent ... Hebt $U$ in de tusschentijd alweer iets gepubliseerd? Ik vraag dit, waar ik persoonlik 'n intensieve belangstelling in Uw werk heb en 't graag voor mij [dan?] bestellen wil...

\subsubsection{Brief 4: 8 Juli 1924}

\subsubsection{Afbakening der 'gewetensverschijnselen' - een oorspronkelijk bijdrage}

Zo juist ben ik uit Keulen aangekomen, alwaar ik onder Prof. Scheler magna cum laude gepromoveerd heb. Met de diss[ertasie] is prof. Scheler heel tevreden [-] wil het zo spoedig mogelik in zijn reeks "Schriften zur Philosophie und Soziologie", waarin Landsbergs diss[ertasie] ook verschenen is, drukken laten ${ }^{26}$. 'k Heb, volgens gewoonte aan de Duitse Univ[ersiteiten] met getypte eksemplaren gepromoveerd en wil enkele gedeelten in ondergeschikte punten wijzigen, voordat ik 't drukken laat. Scheler zegt dat met de centrale afbakening der "gewetensverschijnselen" van de overige verschijnselen in ons zedelik bewustzijn, ik 't gewetensprobleem veel verdiept heb en veel oorspronkelik werk geleverd heb.

21 Der Romerbrief: zic Barth (1933).

22 J. Böhme (1575-1624), Duits protestant mystikus

23 Misschien studies voor Scheler, Die Formen des Wissens und der Bildung (1925), of Scheler, Die Wissensformen und die Gesellschaft (1926).

24 Het laatste door Scheler gepubliccerde artikel "Philosophische Wcltanschauung" (1929) geldt als een schets van de opbouw van Scheler's metaphy'sika; manuskripten met betrekking tot de uitwerking ervan werden pas 1979 in band 11 van de Gesammelte Werke gepubliceerd.

25 Waarschijnlijk cen voorstudic voor Scheler, Die Stellung des Menschen im Kosmos (1928) opgenomen in band 9 van Gesammelle Werke.

26 De dissertatic van Stoker wordt in 1925 als deel 2 van de door Scheler uitgegeven recks "Schriften zur Philosophie und Soziologic". gepubliceerd: HG. Stoker. Das Gevitsien: Erscheinungsformen und Theorien (1925). Decl 1 van de recks was: P.L. Landsberg. Wesen und Bedeutung der platonischen Akademie (1923). 


\subsubsection{Een geweten ook bij dieren?}

Van Uw theorie over Mensch vs. Dier heb ik veel gebruik gemaakt in de vraag of dieren ook 'n geweten hebben. De diss[ertatie] is verbazend lang geworden en ik zal op een of andere wijze 't moeten inkorten voordat ik 't drukken laat, ' $t$ is 428 typpaginas groot. Dit alles hoop ik a.s. November te doen, wanneer ik v[an] Afrika terug ben, waarheen ik nu voor 'n 4 maanden vakansie vertrek ...

\subsubsection{Brief 5: 21 Juli 1924}

\subsubsection{Zeereis-dagen: subjektieve phantasie en objektieve realiteit}

Hooggeachte Professor,

't Is 'n genot alle inspanning en zorg van je af te gooien en heerlik op dek in zonof maneschijn in ' $n$ half-werkelike en half-dromerige toestand over de grote oceanen heen te glijden. Alles, de jaren die nu juist voorbijzijn, de ogenbliklike omgeving en de roepende toekomst schijnen me een droom, ' $n$ heel mooie droom, toe. 't Is heerlik niet te denken en al half-dromend de phantasie vrije spel te laten. Ogenblikken zoals onze eerste ontmoeting, Uw voorlezingen in Köln 27 met al wat daaraan verbonden was, en zo heel veel meer krijgen dan opeens nieuwe en diepere betekenis. Veel wat eenmaal werklik was, schijnt me in 'n ietwat romanties gewaad gehuld, waardoor ik enkele ogenblikken even nadenken moet of ik zelf dit alles beleefd heb - en of 't droom of gelezen was. Schoon is 't wel 't verleden in deze nieuwe kleuren terug te zien; schoon ook in de groots $\{s\}$ te toekomst-dromen te verdwalen.

In zulke stemmingen gingen de eerste zee $\{-\}$ reis-dagen voorbij. Nu is er leven aan boord, nu voel en tast ik de realiteit in al die sports en oefeningen en bewegingen - waar ik vroeger ook zo graag aan meegedaan heb. Des te meer inspanning, des te meer tegenstand [-] des te reëler ${ }^{28}$ voel ik de realiteit om mij; 't is geen droom, geen phantasie als ik moeg en buiten adem me weer in die heerlik luie dekstoel neervlei en de ogen weer over die ontelbare golven dwalen laat, om zo nu en dan vaag in de verte 'n langzaam bewegende grijze stip te ontdekken - 'n ander schip op die onmetelike oceaan.

27 Buytendijk sprak in de jaren twintig herhaaidelijk voor de Kculse afdeling van het 'KantGesclischaft"

28 Vgl.: "Dic kernthese Schelers ist nun, dass Realität in einem Widerstandserlebnis gegeben sei. dass Realität der Inbegriff all dessen sei, 'was gegen unser Streben Widerstand ausübt" (Scheler, Gesammelte Werke, 9:78). Ook Mader (1980:64). 


\subsubsection{Nadenken over karakter en persoonlijkheid}

Als dan na zulke oefeningen 't bloed wat vlugger door de aderen zich beweegt, dan verdwijnt de subjektieve phantasie en maakt plaats voor gedachten die over de objektieve realiteit iets uitzeggen willen. Dan denk ik wel eens terug aan de dissertasie of aan zoveel wat ik van Prof. Scheler geleerd heb, maar meer nog konsentreren zich de gedachten op dat, waaraan ik nu mijn krachten in de eerste plaats geven wil: wat is Karakter? Persoonlikheid? In hoever hangt "Karakter" prinsipieel af van de tegenstelling tussen geest en leven ${ }^{29}$, \& van de tegenstelling tussen goed en kwaad als objektieve realiteiten? Waarin is de eenheid van geest en leven te zoeken in de mensch? We kunnen mischien wel zeggen, waar leven is, is psyche. Psychisch is dan net de innere zijde van 't levenszentrum; en in deze zin kan een plant ook wel "psychisch" zijn, al is dit net in 'n "onbewuste gevoelsdrang" 30 . Maar is "Ziel" niet meer als psyche? Alle levende wezens hebben psyche - maar "ziel" heeft de mens alleen" ${ }^{31}$ - en deze ziel is mischien die eenheid waarin zowel geest als psyche versmelten, waarin de geest gevitaliseerd en 't leven vergeest[e]likt wordt ${ }^{32}$. En is dan niet juist in deze eenheid de kern van 't karakter- en persoonlikheidsvraagstuk te zoeken? En is dit probleem niet daarom zo moeilik omdat we de onoverbrugbare dualiteit van geest en leven (natuur) zo scherp raakzien en hun eenheid in de menslike ziel voorbijzien ${ }^{33}$ ?

Is dit probleem niet juist noch ${ }^{34}$ meer verduisterd omdat deze dualiteit van geest en leven verscherpt wordt door de dualiteit van 't goede en 't boze? Heeft misschien niet juist ' $t$ reële boze de ziel uiteen gescheurd in geest en natuur welke nu zo onlogenbaar vijandig tegenover mekaar staan zodat de een de ander zoekt te overheersen en te tyranniseren? En ligt niet juist in 't wezen van "karakter" dat er 'n stabiliteit tussen deze antipoden ingetreden is? - Zuiver biologies 't "ka-

$29 \mathrm{Vgl}$. de context van noot 9 en 10.

30 Vgl. "diese erste Stufe der Innenscitc des Lebens, der Gefuhlsdrang" (Scheler, Gesammelte Werke, 9:16)

31 Vgl.: "Der Mensch allein - sofem cr Person ist - vermag sich über sich - als Lebcwesen emporzuschwingen und von einem Zentrum gleichsam jenseits der raumzeitlicher Welt aus alles, darunter auch sich selbst, zum Gegenstand seiner Erkenntnis zu machen. So ist der Mensch als Geisteswesen das sich selber als Lebewesen und der Welt überlegene Wesen" (Scheler, Gesammelte Werke, 9:38).

32 Vgl.: "In de onmiddellijkheid van het leven en samenleven kennen wij onszelf met volstrekte zekerhcid als een lichamelijk zijn, een bezield lichaam en een geincarneerde bezicling" (Buytendijk, 1965:77).

33 Voor het probleem van eenheid en twecheid zic: A.A. Bcijk, "Dier en mens, cen en twec Dubbelzin in het denken van Max Scheler en F.J.J. Buytendijk", manuskript 1992.

34 Mischien: veel (Stoker schrijft meestal nog maar soms noch en toch). 
rakter" vast te leggen als sanguinies, phlegmaties, enz. heeft wel 'n zin, maar is de specifieke zin van "karakter" niet veel meer? Zuiver geestelijk 't "karakter" vast te leggen als heilig, zondig, heeft wel 'n zin, maar is ook hier niet de specifieke zin veel meer? En ligt dit "veel meer" niet juist in die eenheid van geest en natuur (leven) welke we in de "ziel" van de mensch vinden?

Zonder dwang, zonder te moeten en te jagen, over zulke dingen na te denken[,] is zeker wel van 't aangenaamste dat er is ..

\subsubsection{Iets over het examen en de dissertatie}

Nu wil ik U eerst eens iets van mijn eksamen vertellen. Mijn dissert[atie] is Prof. Scheler goed bevallen en hij heeft 't met 'n "sehr gutes sehr gut" als praedicaat beoordeeld - niet "ausgezeichnet" - want daarvan ben ik zelf overtuigd "ausgez[eichnet]" verdient mijn diss[ertatie] niet. Enkele punten was hij minder tevreden mee, maar met de kern van 't werk, 't terugbrengen van 't geweten op 't reële materiale ${ }^{35 a}$ persoonlik "Böse" was hij biezonder ingenomen. Hij wil onder alle omstandighede mijn diss[ertatie] in zijn Sammelwerk, waar Landsbergs diss[ertatie] in verschenen is, uitgeven. Hierover ben ik heel blij, want dat is voor mij aan de ene kant 'n eer, en aan de ander kant ' $n$ kriterium van de kwaliteit van mijn werk, waarover ik zelf dikwels heel onzeker was; 'k heb mis[s]chien bij 'n te grote vertroue $\{n\}$ in alles rondom mij te weinig vertroue tot dusver in mezelf gehad. Zulke resultaat vestigt 'I zelfvertrouwen, wat veel waard is, - al zit er tegelijk 't gevaar in te zelfbewust en zelfzeker te zijn, waarvoor ook opgepast worden moet. Mijn mondelinge eksame[n] was wel goed maar ik zelf ben ontevreden erover. Ik ben geen spreker, - onmiddellik op vragen mondelings te antwoorden of in publiek te spreken[,] is mijn zwakpunt, - terwijl ik me in 't schrijven des te zekerder mee voel. 'n Schriftelik eksame[n] kan ik veel beter. Scheler heeft dan ook gezegd ik weet veel meer, als ik geantwoord heb. 'k Heb toch in 't eksamen voor 't mondeling 'n "sehr gut" - magna cum laude [-] gekregen en voor 't geheele (diss[ertatie] \& mondel[ing]) ook 'n magna cum laude.

\subsubsection{4 lets in Scheler's karakter ... dat met een punt in mijne overeensloot}

Hiernee ben ik aan 'n mijlpaal in mijn leven gekomen. Heel wonderlik is wel Gods leiding dat ik zo voor onze ogen toevallig van $\mathrm{Dr}$. Los bij $\mathrm{Dr}$. Vollenhoven en door hem met $U$ en door $U$ met Scheler in aanraking gekomen ben. Nu ik de tegenwoordige Philfosophie] in Duitsland wat beter ken, ben ik overtuigd dat U me nooit beter hebt kunnen raden als naar Scheler, en ben ik er innig dankbaar voor dat ik door U Prof. Scheler gevonden heb. Zijn diepzinnigheid, zijn scherp-

35 Term waarschijnlijk gebruikt samenhangend met het Duitstalige intellectuecl milieu van de disscrtatic. 
zinnigheid, zijn ongekende algemene ontwikkeling, en dan zijn ernstig zoeken naar de oplossing van raadselen die diepste wortele[n] van alle zijn raken - zijn voor mij van de grootste voordelen geweesd. Dankbaar ben ik in biezonder dat ik de eer gehad heb zo persoonlik met Scheler bevriend te worden, hem zo van nabij te leren kennen en van hem te leren houden. Er is iets in Schelers karakter, iets ergens heel diep, dat met 'n punt in mijn karakter overeensloot - ik ben overtuigd dat Scheler zelf 't gevoeld heeft en deze resonanz $3^{35}$ ook zijn deel gedaan heeft ons te bevrienden. Werkelik 't deed me spijt die dag toe ik weg moest van Scheler afscheid te nemen. - De mensen mogen over hem kletsen wat ze willen, ik blijf hem als mijn leermeester eeren en waarderen.

\subsubsection{Dankwoord aan Buytendijk}

Deze gelegenheid wil ik nu gebruiken $U$ persoonlik hartelik te bedanken voor alles wat $U$ in deze jaren voor me gedaan hebt. Heel veel ben ik $U$ verplicht en zal er heel mijn leven dankbaar voor zijn - niet alleen hiervoor dat $U$ me zo hartelik geholpen hebt met Scheler in aanraking te komen, maar vooral hiervoor dat $\mathrm{U}$ persoonlik mij tot $U$ getrokken hebt en die uren die we tezamen waren[,] mij gegeven hebt waarvoor U U persoonlik interesseert. Mijn studie in Europa draagt duidelike sporen van Uw invloed en ook mijn toekomstige werk zal aantonen van hoeveel en hoe groot belang ook $\mathrm{U}$ voor me geweesd bent. Van harte hoop ik, dat al zal in de toekomst 5-6000 mijlen zeewater ons scheiden, \{dat\} die band die in de enkele uren van ons samenzijn gegroeid is[,] niet verbroken maar integendeel steviger worden zal.

Wat mijn toekomst betreft is alles nog heel onzeker. Waarschijnlik wil Potchefstroom mij vanaf $1 / 2$ Maart 1925 daar aanstellen. Gebeurt dat, dan kom ik November voor 1 semester terug en om geen tijd te verliezen (wat aan 'n vreemde univ[ersiteit] noodwendig gebeurt) zal ik dan weer naar Keulen gaan. 't ls hoofdzakelik te doen om de problemen: Karakter en opvoeding[,] $\{-\}$ de grenzen $\mathrm{v}$ [an] $\mathrm{d}[\mathrm{e}]$ zielk[undige] eksperiment, $\{-\}$ en Kinderpsigologie. Gevell ze me in Potchefstroom langer uitstel, dan ga ik waarschijnlik November naar Wenen en zal noch zien waarheen ik me 't volgend Somer semester wenden zal. Als er niets onverwachts in de weg komt, kom ik dus in elk geval Nov[ember] weer naar Europa - en hoop van harte $U$ dan nog enkele male persoonlik te kumnen spreken. 't Spijt me wel dat ik $U$ nu niet lieb kumnen ontmoeten $\{\}-$,$U was waarschijnlik voor va-$ kantie weg.

\footnotetext{
$35^{\mathrm{b}}$ Term waarschijnlijk gebruikt samenhangend met het Duitstalige intellectucel milicu van de dissertatic.
} 


\subsubsection{Brief 6: 1 September 1924}

\subsubsection{1 "De Afrikaanse zon is iets ongekends kosteliks"}

$\mathrm{Na}$ 'n prettige zeereis kwamen we eindelik in Kaapstad aan. Deze haven maakte 'n diepe indruk op me en verwekte ' $n$ gemengd gevoel, eensdeels de vreugde mijn vaderland weer te zien na $2 \frac{1}{2}$ jaar verblijf in de vreemde, anderzijds de bewondering van die majest[u]euse en grootse Tafelberg, 'n stuk natuurschoon, zoals er min in de wereld te vinden is, - dan weer 'n intens verlange zo spoedig mogelik agter die Tafelberg diep in 't bimnenland in te sporen waar mijn meisje en mijn ouders op me wachten, en ten slotte 'n bevredigd gelukkig gevoel, dat mijn Europese studie met goed gevolg afgesloten is en tegelijk weer 'n klein beetjie "hartseer" dat ik Europa met zijn heerlijke voordelen vooral op wetenschappelik en kunst-gebied missen moet. Dit gemengd gevoel werd echter spoedig door de doeane-beampten op zij gedrongen, de praktische handelswerkelikheid eiste al mijn aandacht, want mijn hele bibliotheek en kleerage moesten door de lange vingers van dit soort noodwendig kwaad heenglijden.

De ontmoeting met mijn familie en mijn meisje kunt $U U$ wel voorstellen. Er is wel geen gemeste kalf geslacht zoals 't geval met de verloren zoon was, maar de vreugde was er niets minder om.

't Is wel 'n genot 't heerlik zonnig Zuid Afrika weer te zien en van zijn kostelik klimaat te genieten. Deze zon kent $U$ in Europa niet. De zon omspant allen hier even hartelik en intiem met zijn uitgestrekte stralen presies zooals 'n hen haar kiekens bedekt. Ik heb in Europa de zon te veel als een vreendeling gevoeld, hier is hij 'n intieme vriend van elkeen; hij wil niet weg van ons en wij willen hem niet laten gaan. Er is geen wolkje aan de hemel welke jaloers de zon voor zich opeisen wil. De Afrikaanse zon is iets ongekends kosteliks. En dan 's avonds die heerlike ope sterre-hemel schitterd hier mooier en intenser als elders. Van horison tot horison door de hemelboog heen schittert de sterrewacht door geen wolkje ontsierd. 'I Is waar[,] na zovele jaren van afwezigheid voelt men de schoonheid van zijn vaderland des te dieper. Vooral nog geniet ik de veruitgestrekte vale grasvlaktes. Voor de bezoeker lijkt dit misschien eentonig en verlaten, maar voor hem, die enkele jaren lang of langer ze heeft leren kennen, zit er 'n warmte, 'n ongekend leven, 'n vriendschappelike band in. Als de zon op deze vlaktes zijn koesterende stralen vallen laat met majest[u]euse weelde en overvloed, dan krijge ze ' $n$ imnig, half misterieuse en half reële toon - en je voelt of je binne in de natuur bent en niet van buite als toeschouwer de natuur beziet. De wijde Afrikaanse veldvlaktes met hier en daar 'n groen-grijze vlek, ' $n$ boereplaats, 'n vlek welke nu nog meer tintelt van schoonheid en levenslust door de licht-rode bloesems, welke tussen de grijse populier bosse en de donkergroene hoge bloegeın-bome afwisselend doorheenstralen[,] heeft zo iets bekoorliks en 
boeiends over zich, dat wie dit meer als 'n jaar gezien heeft ook hier niet weg kan en als hij moet er altijd intens naar terug verlangt.

\subsubsection{Kwalitatief en kwantitatief vooruitgang van de "Dopper"-kollege}

Enkele dagen ben ik in Potchefstroom geweesd, waar mijn alma mater streeft, zwoegt en begint te bloeien - ik mag wel zeggen "bloeien", want ze zijn daar in de laatste $2 \frac{1}{2}$ jaar verbazend vooruit gegaan kwalitatief en kwantitatief. Toen ik wegging[,] spartelde deze "Dopper-Kollege" (Dopper = gereformeerd, 'n scheld, d.w.z. eere-naam) om zijn leven te redden met 30 studenten voor alle vakken, - nu hebben ze er 165 en verwachten 't volgend jaar over de 200. De staf is aanmerkelik verbeterd en de regering (na de laaste omwentelingen) veel gunstiger gezind. De literaire, filosofiese, zielkundige, opvoedkundige en theologiese fakulteiten zijn 't sterkste; de natuurwetenschappelike volgen dan, en 't zwakste, eigenlik nog in zijn begin, staat de staatkundige afdeling; 'n mediese fakulteit hebben we niet.

Deze Dopper-Univ[ersiteit] Kollege is de enigste in Afrika welke zich op de waarheden van de Bijbel vestigt en geloof en weten in eenheid tracht te doseren. Alle ander Universiteiten staan min of meer op 't Engels-Amerikaans $\{-$; empieries-pragmatisties-evolutionistiese standpunt. De golf van Evolutionisme ${ }^{36}$, zoals die in 1875 - 1910 over Europa geweldig stroomde, is sinds 1910 - vandaag bij ons en is misschien vandaag op zijn hoogtepunt en rukt helaas ontelbaar vele jonge Afrikaners van hun ouderlike tradieties weg. Hier moet gewerkt worden. Prof. Dr. du Toit, onze Dopper-dichter, heeft 'n serie lezingen tegen 't cvolutionisme gehouden en heeft mij gevraagd in die lijn voort te gaan, - maar hierover later. Met enkele leiders van Jong Zuid Afrika, - o.a. Prof. v[an] Rooy (ook $P[o t] c[$ hef] stroom) heb ik over $U$ gesproken en spontaan vroegen ze me of $U$ niet gewillig zoudt zijn evenals zovele Hollanders in de laatste tijd (Casimir, Pont, Kuyper, Saumerijs[?], Hullebroek) ${ }^{37}$ 'n serie voorlezingen over heel Zuid Afrika te houden, a. wetenschappelik vooral aan de Universiteiten, b. meer populêrwetenschappelik voor de onderwijzers en ontwikkelde bevolking in de steden - 't geen ik van mijn [kant] sterk aanmoedigde. Vooral wij in P[ot]c[hef] stroom voelen de wenselikheid en noodzakelikheid van Uw komst als Europese outoriteit om t[e] helpen de Evolusie Overstroming hier tegen te gaan ${ }^{38}$. Als $U$ gewillig

Bedocld wordt de cvoluticleer zoals dic voor het cerst verkondigd werd in Ch. Darwin. The Origin of Species (1859).

37 R. Casimir (1877-1957), Nederlands pedagoog. J. Pont (gest. 1939). Nederlands theolong; H. Kuyper (1864-1945), Nederlands gereformecrd thcoloog. Saumerijs?: E. Hullcbrock (1878-1965), Vlaams komponist

38 Voor Buytendijk's opvattingen inzake de cvolutieleer zie: H. Struyker Boudier, Mier en slang (1990). 
zoudt zijn ${ }^{39}$, zullen wij in Afrika alles voor $U$ regelen. Hierover hoop ik in November nog met $U$ te kunnen spreken, en dan zal van 'n $Z$ [uid] Afr[ikaanse] Organisasie later de uitnodiging volgen.

\subsubsection{Steunpilaren van de Potchefstroom Universiteitskollege}

Met Prof. Dr. Du Toit (onze Theoloog en Dichter), 'n man waar ik verbazend veel respekt en hoogagting voor gevoel, - de ziel bijna van 't Kalvinisme in Zuid Afrika, 'n deemoedig hart met 'n geniale aanleg en hooge werk-kracht, - heb ik over $U$ gesproken. Hij zou $U$ heel graag ontmoeten, en hij zal veel beter met $U$ als met Prof. Hepp kunnen opschicten. Hij is ook phänomenoloog zonder het te weten, al was zijn opleiding intellektualisties. Zijn dichter-ziel waarborgt de egte intuitie in hem. Hij is nu bezig met de Bijbelvertaling van 't Hebreeuws, Gricks, Hollands en Engels en Duits in 't Afrikaans - 't is 'n lang gevoelde behoefte in ons volk geweesd Gods Woord in onze eigen moederspraak, Afrikaans, te mogen bezitten. Naast hem ... zou ik U onze Rektor, Prof. Dr. Postma willen noemen, 'n Classicus, cen van de beste outoriteiten in 't Grieks en Latijn, die we in Afrika hebben, 'n organiseerder en idealist wat die P.U.K. (Potchefstroom Universiteit Kollege) betreft. De bloei van onze lnrigting is biezonder veel aan zijn aanhoudende ijver en inspanning te danken, vooral in de dagen van de strijd voor leven of dood.

In de onlangst overleden Prof. Kanp hebben we de beste Kunst-criticus van Afri$k a$ verloren. Hij was ' $n$ levend decl aan de P.U.K. en was biezonder geliefd onder allen. Hoogwetenschappelik en ietwat mysticus, vol besieling voor zijn levenstaak wist hij in zijn klasse de studenten te boeien zoals geen twede. Vooral door deze drie is het, dat de P.U.K. 'n hoopvolle toekomst tegemoet kan zien. Onder de jongeren moet ik nog in biezonder noemen: Prof. v[an] Rooy, de filosoof. Ook aan hem is de P.U.K. biezonder veel verpliclıt en hij zal al meer en meer later ' $n$ waardige plaatsvervanger van de oudere Professoren zijn.

Deze mannen noem ik om de besliste en harde strijd die ze voor de P.U.K. afleggen, met wie ik zelf ook later hoop mee te strijden. Twee nuwe stoelen moeten opgevuld worden: a. Opvoedkunde en Methodik, b. Sielkunde, Logika en Filosofie $v[a n] d[e]$ Opvoedkunde. a. Is aan een manmetjie van staal aangeboden: J.C. Coetzee ${ }^{40} \mathrm{en} \mathrm{b}$. aan mij. Mijn stoel is voorlopig 'n senior lektorschap (= privaat dosent, die 'n vaste salaris ontvangt en verantwoordelik is voor de eksamens

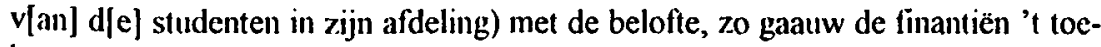
laten ' $t$ in 'n Professoraat te veranderen. (15 Febr[uarie] moet ik beginnen; 15 Okt[ober] - 15 Febr|uarie] hoop ik D.V. 'n afsluitende reis naar Europa te doen,

40 J C. Coctzec, Zuid-Afrikaans psycholoog en pedagoog (hoogleraar en later Dekaan Facultcit Pedagogick en ten slotte Rector van de PU vir CHO. Potchcfstroum). 
terwille van 't drukken van mijn dissertatie en van enkele problemen die ik nog daar aanpakke wil).

De finantieële kant v[an] d[e] P.U.K. is wel niet zo rooskleurig. Vroeger moesten ze in private woonhuizen klas geven. Nu hebben ze 7 langwerpige zink-gebouwen opgericht om klas in te geven. Al te aristokraties ziet dat wel niet uit; maar de lessen zijn er niks minder om. 't Ware werkelik te wensen, dat 'n rijke persoonlikheid eens 'n heel stevige donatie aan de P.U.K. gaf - in Afrika is er weinig kans op, 't volk is arm; als zo iets komt zou 't van 'n Kalvinist in Holland of Amerika moeten komen - en daar is zeker ook niet veel kans op.

\subsubsection{Enkele vragen aan prof. Buytendijk}

Hooggeagte Professor, voor ik een en ander over mijn studie in Europa schrijf, zou ik $\mathrm{U}$ graag enkele dingen willen vragen:

\section{(1) Inleidende kursus in eksperimentele zielkunde}

O.a. moet ik 't volgend jaar 'n inleidende kursus op eksperimentele zielkunde geven. Zou u mij s.v.p. raad en wenken willen geven betreffende 't inrichten van 'n eksper[imenteel] psych[ologisch] laboratorium, 't uitkiezen en aanschaffen van apparaten welke voor een 1-jarige kursus als inleiding dienen moeten, en 't aanbevelen van enkele goeie handboeken op dit terrein? Ik vraag $U$ dit, daar ik overtuigd ben dat Uw rijke ervaringen op dit gebied mij van biezonder veel vrucht zijn kunnen en zullen.

\section{(2) Weerlegging van de evolutieleer}

Op 't gebied der biologiese evolutie-problemen heeft Prof. du Toit 'n serie lezingen gegeven en heeft me gevraagd die aan te vullen en ' $n$ brochure crover te schrijven, - hij heeft absoluut geen tijd daarvoor, - wat vooral tegenwoordig van groot belang in ons land is, om de jonge Afrikaners op de andere Universiteiten van andere standpunten en beschouwingen op hoogte te brengen. Prof. Du Toits wens is, dat de weerleggingen van de Evol[utie]-leer zo min mogelik door bespiegelingen en wereldbeschouwings-argumenten geschieden moet, maar door aanhalen van konkrete harde werkelike feiten, welke aantonen dat de Evolutie-leer nog niet bewezen en ook slechts dogma of hypothese is. De Professoren aan de andere Univ[ersiteiten] hier zeggen: Jullie weerlegt ons altijd met filosofiese argumenten, - breng liever konkrete feiten, dan kumen we notitie ervan nemen. Zoudt $U$ me s.v.p. ook hierin willen helpen zoals $U$ zelf ' $t$ het geschikste acht? Bijv[oorbeeld] door me op enkele feiten te wijzen en door me 'n bibliographie aan te bevelen, welke me vooral konkreet van nut en waarde zijn kan. U zoudt 
me werkelik biezonder verplichten en ons 'n grote dienst bewijzen als $U$ me hierin behulpzaam zijn kondet.

'k Hoop $\pm 9-11$ November en dan weer de Kerst- en Nuwe Jaars dagen in Holland te zijn en $U$ op te zoeken. Ingeval $U$ me dan op vragen 1, en 2. antwoorden geven kunt, zal ik dankbaar en blij zijn.

\subsubsection{Terugblik op een onvergeetlijk Europese studie}

Als ik terugzie op mijn Europese studie, dan ben ik werkelik innig dankbaar dat ik $U$ en Scheler ontmoet heb, en dat ik onder Scheler zo lang heb mogen studeren. U hadt me niet beter raden en helpen kunnen; ' $k$ heb bij hem zo ontzettend veel geleerd en diepe inzichten gekregen, 'k geloof geen twede, geen Stern, of Cassirer, of Spranger, of Litt, of Dessoir, of Messer, of Rickert ${ }^{41}$, of wie ook zou me, zelfs in de verte niet, van zoveel waarde geweesd zijn als juist die Scheler. ' $t$ Is wel 'n wonderlike bestiering, dat $i k$ van Dr. Los tot Dr. Vollenhoven ${ }^{42}$, van $V$ [ollenhoven] tot $U$ en van $U$ tot Scheler gekomen ben. - Mijn dissertatie wordt in Desember gedrukt en ik zal zorgen, dat zo gaauw die verschijnt ${ }^{43} \mathrm{U}$ 'n eksemplaar toegezonden wordt.

De uurtjes die ik of bij U alleen, of bij $U$ en Scheler, of bij U, Scheler en anderen, doorgebracht heb, blijven onvergeetlik. Met 'n innig genoegen denk [ik] daaraan terug en zal er altijd met veel genoegen aan blijven terugdenken. Deze uren zijn werkelik van de mooisten en waardevolsten tijdens mijn Europese studie geweesd.

Er is nog zoveel om over te schrijven en te gezelsen, vooral als er zovele duizende kilometers tussen ons ligt, - maar ik hoop toch spoedig met $U$ persoonlik te kunnen spreken en zie er werkelik met verlangen naar uit.

Met de hartelike groeten, ook aan Uw familie,

en met uitnemende hoogachting,

Uw toegenegen

Hendrik G. Stoker.

41 Betreft: W. Stern (1871-1938), Duits filosoof en psycholoog; E. Cassirer (1874-1945), Duits filosoof, E. Spranger (1882-1963), Duits filosoof, psycholoog en pedagoog; Th. Litt (1880-1962), Duits filosoof en pedagoog; M. Dessoir (1867-1947), Duits psycholoog en filosoof; A. Messcr (1867-1937), Duits filosoof, psycholoog en pedagoog: H. Rickert (1869-1940), Duits filosoof

42 S.O. Los, thcoloog en predikant, voor enkele jaren docent aan de Potchefstroom Universitcit Kollege: D.H.Th. Vollenhoven (1892-1978), Nederlands filosoof, hoogleraar aan de Vrije Universiteit van Amsterdam (1926-1963).

43 Zie noot 26. 


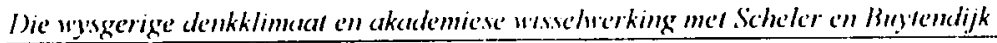

5. Uit de pen van II.G. Stoker

(Brief 3: 6 Mei 1924)

bei tehen nowert SG 28 . Käer.

Jegachle

6. 5.24

Qrof. Sn. Bajitandigh.

Nect betwblin tot mï vorig prief wil it 4 grang meedele, dat

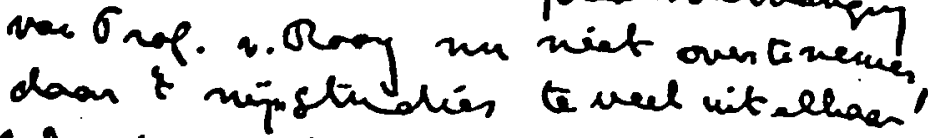

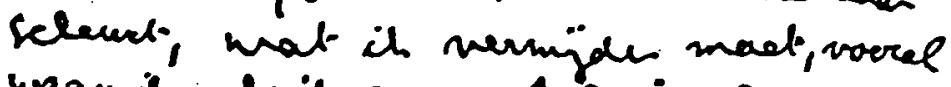

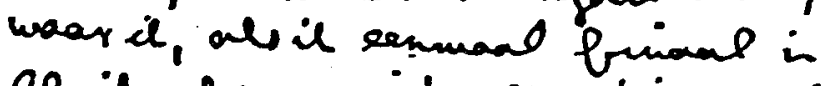
april ke. mitwen die grote gelepunteid heblen zal mi gopoed als magelie nor mï tachomigis Rarfin voort levide. Ale teque avoustol hat il Grol.u.Roy gevarat of hy iir gtudi plamme viet en pion nit. stelle kou, dace zor il it wel a ammence 'kummes, gonde. inctrecke of unip studies 6 mathen.

hes beyf ih ranal xovember nap tive senestiv is Euafa, emidui is maiand of 6 is ameriha of rugeloud. react - appil 1926 hen il binaro of

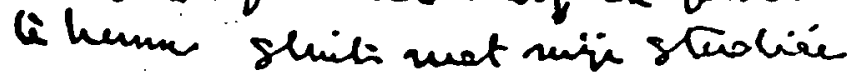

524

Noers $59(3 d+1994: 501-528$ 
Armold A. Beijk \& N.T. van der Menue

i't buitan Bland en met vable bequitip

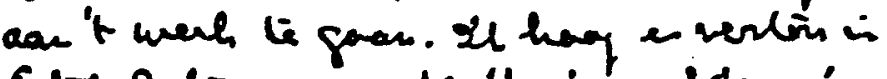

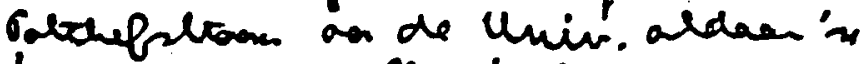
henorming zulle kiggen.

mü dissenteri is plublix

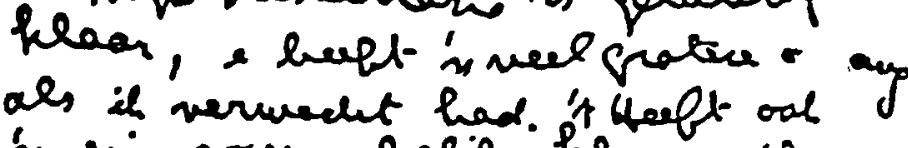

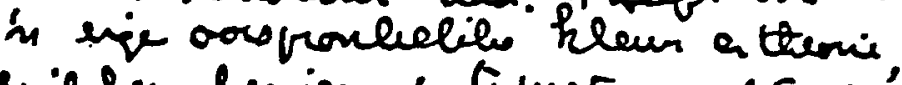

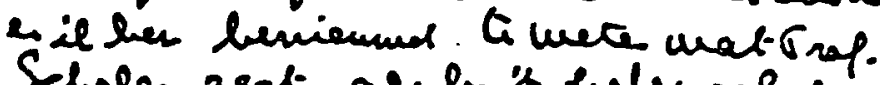
Schaler zept, at by it helemaegselen heepl. miij prond then is: mict.

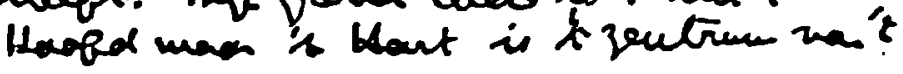

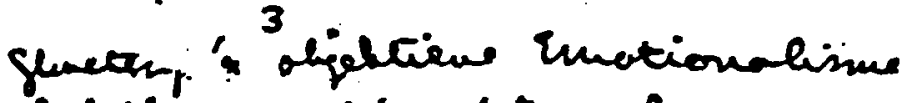
beb il vergereht unt te werken. in Inede groud there is: 't Gewer, mannees 't wit hosischureate biologiers is joinole agfunt beardeced mondt, minet noodungy

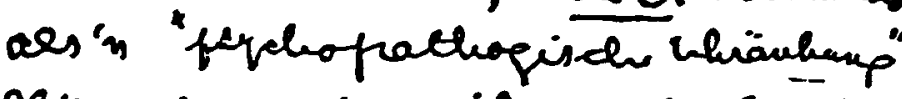
alugrie uode; mil muen do tunst

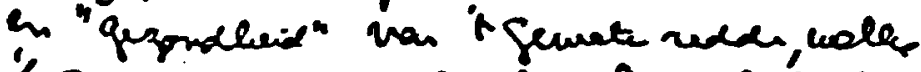
' Senere asser in viclzelue, betwet, metrity iber-bialogioch e. ihe segial oogfunt besibound

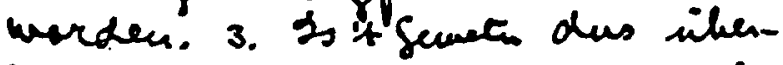
bial. en ïles seg. als in dief-inmip

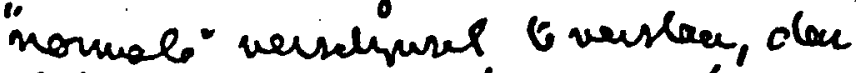
is 't Nutaplesies tap ween's

Koer. 59(3\& 1) 1994:501-528 525


Die wysgerige denkklimaat en akademiese wisselwerking met. Scheler en Buytendijk

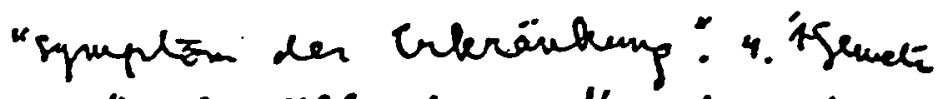
als" dis reille inere Kunduerd cy des personal bö̈sen in uns - ses es vervirhbiut (bözes gumisen), sei es yer Veruvirbliehump drängend.

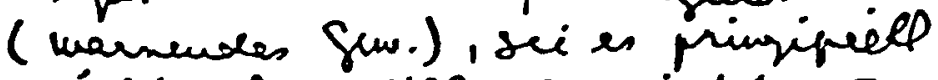
méghich ales reiel verneint ( quas qevirce), is absolunt vertranbaar es

"urpelbbor." "̈aut, miet de KenTeoutisise mitypoal oven wat poear of huread is, moan de warkbial dat mel of niet in ons iels "Böses" quel in ar leviegt beeft is de inhord wan

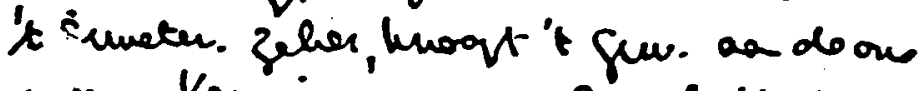
"sye Kennis gegerven. Boosheid aan, nuseen "t Kenmen des "Bozen" is nap geen gevere, - it als haos, sond;- erbende act $t$ wille a hegere, of ti veryite maerones 't gumeti ziel hehommend. Wot il abs slucht erber en wil, - dat il

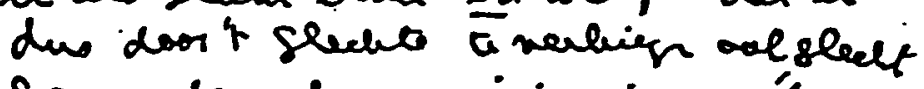
ben, - dezg by neipin. i cus, "t, baze pringief ious, reageet' tgencer

$\overline{526} \quad$ Kerers $59(3 \& 4) 1991: 501-528$


Armold A. Beyk d' N.T. wan der Menue

tep, mit té de Kemmis van't boge. in lieni ist $A$ - Geuet confeilleen, eve on poilbanals il in in hat od werthat's haat a gren hefole in, dis. it racel.

ass min diss entali pepublisend moref, zal it 4 onmiddellie th stiven. Iot" dusver workt't ney net is is aqutes lisemplare getift, wanner is stal de Unim abgiven mact.

Hebt $U$ i de tivschutges alueer iets gifublivines? Il. voay dit, veadic perrooulie is nitins iens belareptelli i Un werk hob \& 't proap noormy a bestet wid. P met de Itacklibe qraete aal aan un fomilie, \& ols meeste hadergti, Unlapges poing onid, $U \cdot S$. Staken.

Nocers $59(38+1) 1904: 501-528$

527 


\section{Bibliografie}

BARTH, K. 1933. Der Römerbrief. München : Kaiser. (Oorspronkelijk uitgave 1919.)

BEIJK, A.A. 1992a. Hart, ziel, geest. Twee brieven van Max Scheler aan F.J.J. Buytendijk. Manuskript.

BEIJK, A.A. 1992b. Dier en mens, een en twee. Dubbelzin in het denken van Max Scheler en F.J.J. Buytendijk. Manuskript.

BUYTENDIJK, F.J.J. 1921. De deemoed. De Reformatie. Weekblad tot ontwikkeling van het gereformeerde leven, 2 (9), dec. 2

BUYTENDIJK, F.J.J. 1922a. Beschouwingen over enkele moderne opvoedkundige denkbeelden. (Verdieping en belijning, $1^{\mathrm{e}}$ reeks, no 19.) Groningen : Noordhoff. (Duitse Vertaling: Erziehung zur Demut. Betrachtungen über einige moderne Pädogogische Ideen. Leipzig : Neue Geist Verlag, 1928; Ratingen : Henn, 1962.)

BUYTENDIJK, F.J.J. 1922b. Bijdrage tot een onderzoek naar het wezensverschil van mens en dier: voordracht georganiseerd door de Vrije Universiteit te Amsterdam, 12 Juli 1922. Amsterdam : Vrije Universiteit.

BUYTENDIJK, F.J.J. 1958. De vormende liefde. (In Buytendijk, F.J.J., e.a. De geneeskracht der liefde. (Serie Geestelijke Volksgezondheid, no. 11.) Utrecht/Antwerpen: Het Spectrum. p. 5-12.)

BUYTENDIJK, F.J.J. 1965. Prolegomena van een antropologische fysiologie. Utrecht/Antwerpen : Het Spectrum.

DARWIN, C.R. 1859. The Origin of Species by Means of Natural Selection. London Murray.

LANDSBERG, P.L. 1923. Wesen und Bedeutung der platonischen Akademie. Bonn : Cohen. [Schriften zur Philosophie und Soziologie, Bd. 1.]

LAP, A. \& STRUYKER BOUDIER, H. 1987. Tijdingen: Brieven van F.J.J. Buytendijk aan Anton van Duinkerken. Zeist : Kerkebosch

MADER, W. 1980. Max Scheler: in Selbstzeugnissen und Bilddokumenten, dargestellt von Wilhelm Mader. Reinbek bei Hamburg : Rowohlt.

SCHELER, M. 1913-14. Zur Rehabilitierung der Tugend. Die weissen Blatrer, 1:360-378. (In Scheler, M. 1955. Gesammelte Werke. Bd. 3. Bern: Francke. p. 13-31.)

SCHELER, M. 1925. Die Formen des Wissens und der Bildung (Vortrag). Bonn : Cohen. (In Scheler, M. 1976. Gesammelte Werke. Bd. 9. Bern : Francke. p. 85-120.)

SCHELER, M. 1926. Die Wissensformen und die Gesellschaft. Leipzig : Neue Geist Verlag. (In Scheler, M. 1960. Gesammelte Werke. Bd. 8. Bern : Francke. p. ?-423.)

SCHELER, M. 1928. Die Stellung des Menschen im Kosmos. Darmstadt : Reichl (In Scheler, M. 1976. Gesammelte Werke. Bd. 9. Bern : Francke. p. 7-73.)

SCHELER, M. 1929. Philosophische Weltanschauung. Bonn : Cohen. (In Scheler, M. 1976. Gesammelte Werke. Bd. 9. Bern : Francke. p. 75-85.)

SCHELER, M. 1979. Gesammelte Werke. Bd. II (Erkenntnislehre und Metaphysik) Bern Francke.

STOKER, H.G. 1924. Gewissensphänomene. Eine psychologisch-philosophische Studie. Manuskript.

STOKER, H.G. 1925. Das Gewissen: Erscheinungsformen und Theorien. Bonn : Cohen. [Schriften zur Philosophie und Soziologie, Bd. 2].

STRUYKER BOUDIER, H. 1990. Mier en slang. Correspondentie van F.J.J. Buytendijk met Erich Wasmann (S.J.). Ingeleid en vertaald door Henk Struyker Boudier. Zeist : Kerckebosch. 